\title{
PENGARUH LINGKUNGAN TEMPAT TINGGAL TERHADAP HASIL BELAJAR MAHASISWA UNIVERSITAS QUALITY BERASTAGI PROGRAM STUDI PGSD
}

\author{
INFLUENCES FROM THE ENVIRONMENT ON RESULTS \\ STUDYING BERASTAGI QUALITY UNIVERSITY STUDENTS \\ PGSD STUDY PROGRAM
}

\author{
Juwita Tindaon* \\ Prodi Pendidikan Guru Sekolah Dasar, FKIP, Universitas Quality Berastagi \\ Diterima: Maret 2020; Disetujui: Maret 2020; Dipublish: Maret 2020
}

*Coresponding Email: wieta.niez@gmail.com

\begin{abstract}
Abstrak
Penelitian ini bertujuan untuk mengetahui pengaruh lingkungan tempat tinggal hasil belajar Mahasiswa Universitas Quality Berastagi Program Studi PGSD khususnya pada mata kuliah Konsep Dasar PKn. Penelitian ini merupakan jenis penelitian kolerasi. Populasi dalam penelitian ini berjumlah 50 orang mahasiswa kelas Universitas Quality Berastagi, dan sampel dalam penelitian ini 50 orang mahasiswa kelas A11 dan A12 Universitas Quality Berastagi karena teknik pengambilan sampel merupakan sampel total. Alat pengumpulan data menggunakan angket dan hasil tes pada mata kuliah konsep dasar PKn. Pada angket terdapat empat pilihan jawaban dan teknik pemberian skor berdasarkan skala Liker, yaitu 1-4. Dari hasil penelitian diproleh data kedua variabel memiliki pengaruh yang signifikan antara lingkunga tempat tinggal terhadap hasil belajar Mahasiswa Universitas Quality Berastagi Program Studi PGSD. Dimana nilai t dalam hitungan= 22,87, dan nilai t dalam tabel $=2,01$. Dimana nilai t dalam hitungan > nilai t dalam tabel maka antara lingkungan tempat tinggal terhadap hasil belajar Mahasiswa Universitas Quality Berastagi Program Studi PGSD memiliki pengaruh.
\end{abstract}

Kata Kunci: Lingkungan, Hasil Belajar, PGSD, Quality

\begin{abstract}
This study aims to determine the effect of the environment of the learning outcomes of the University of Berastagi Quality Students PGSD Study Program, especially in the Civics Basic Concepts course. This research is a type of correlation research. The population in this study amounted to 50 students from the Quality Berastagi University class, and the sample in this study was 50 students from A11 and A12 students from the Quality Berastagi University State Elementary School 101846 because the sampling technique was a total sample. Data collection tools using questionnaires and test results on the basic concept courses Civics. On the questionnaire, there are four answer choices and scoring techniques based on the Liker scale, namely 1-4. From the results of the study, the data obtained by the two variables have a significant influence between the environment of a residence on the learning outcomes of the University of Berastagi Quality Study Program PGSD. Where is the value $t$ in the count $=22,87$ and $t$ in the table $=2,01$. Where the $t$ value in count $t$ value in the table, then the environment of the residence to the learning outcomes of the University of Berastagi Quality Study Program PGSD has an influence
\end{abstract}

Keywords: Environment, Learning outcomes, PGSD, Quality

How to Cite: Tindaon, Juwita. (2020). Pengaruh Lingkungan Tempat Tinggal Terhadap Hasil Belajar Mahasiswa Universitas Quality Berastagi Program Studi PGSD. Journal of Natural Sciences. Vol 1 (1): 17-24

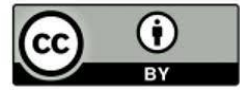




\section{PENDAHULUAN}

Belajar merupakan upaya manusia untuk memperbaiki kualitas diri, menunjukkan adanya perubahan, modifikasi tingkah laku atau pengalaman manusia yang menghasilkan kemajuan dan berhubungan dengan perubahan. Perubahan yang dimaksud adalah perubahan dari seseorang yang tidak tahu menjadi tahu, bukanlah perubahan yang dimana seseorang bertambah berat, tinggi atau dengan kata lain bukanlah perubahan fisik. Sary (2015:180) mendeskripsikan "Belajar adalah sebuah proses perubahan prilaku yang didasari oleh pengalaman dan berdampak relatif permanen".

Dalam mencapai hasil belajar banyak faktor yang mempengaruhinya, yaitu faktor internal (dari dalam diri mahasiswa) dan faktro eksternal (dari luar diri mahasiswa). Faktor yang berasal dari dalam diri yaitu berupa keadaan jasmani dan rohani siswa. Sedangkan faktor dari luar diri yaitu kondisi lingkungan di sekitar siswa (Muhibbin, 2015:129). Lingkungan tempat tinggal menjadi bagian dari faktor internal yang mempengaruhi hasil belajar seseorang mahasiswa. Lingkungan tempat tinggal yang dimaksudkan peneliti adalah lingkungan tempat tinggal kos dengan lingkungan tempat tinggal yang bersama orang tua ataupun keluarga.

Berdasarkan pengamatan yang dilakukan oleh peneliti, lingkungan tempat tinggal kos yang ditinggali oleh mahasiswa tidak semuanya diawasi oleh pemilik kos, terkadang pemilik kos membebaskan mahasiswa untuk melakukan apa saja di lingkungan kosnya, seperti pulang larut malam, membawa teman yang tidak baik. Namun tidak semua lingkungan tempat kos mahasiswa membebaskan mahasiswa untuk melakukan tindakan yang tidak baik, banyak juga tempat kos yang membuat peraturanperaturan yang harus dipenuhi oleh mahasiswa yang tinggal dikos tersebut. Sedangkan untuk mahasiswa yang tinggal bersama orang tua cenderung memiliki lingkungan tempat tinggal yang baik, karena lebih di awasi oleh orang tua, baik teman bergaul maupun jam pulang mahasiswa dan juga jam belajarnya.

Bertolak dari pembahasan di atas maka dapat disimpulkan lingkungan tempat tinggal yang baik akan mempengaruhi hasil belajar mahasiswa. Lingkungan tempat tinggal yang dimaksud dalam penelitian ini adalah lingkungan tempat tinggal kos dan lingkungan tempat tinggal kos. Yang menjadi populasi dalam penelitian ini adalah mahasiswa Univeristas Quality Berastagi, Fakultal Keguruan dan Ilmu Pendidikan, Jurus PGSD kelas A11 dan A12 yang berjumlah 50 orang. Sedangkan yang menjadi sampel 
adalah seluruh mahasiswa Univeristas Quality Berastagi, Fakultal Keguruan dan Ilmu Pendidikan, Jurus PGSD kelas A11 dan A12 yang berjumlah 50 orang.

\section{METODE PENELITIAN}

Penelitian ini merupakan penelitian korelasi, dimana menurut Sumadi (2012:82) menyampaikan "Penelitian kolerasi bertujuan untuk mendeteksi sejauh mana variasivariasi pada suatu faktor berkaitan dengan variasi-variasi pada satu atau lebih faktor lain berdasarkan pada koefisiens kolerasi". Adapun tahapan-tahapan dalam penelitian ini adalah sebagai berikut ini:

1. Tahap Persiapan

a. Menyusun instrumen angket atau kuisoner untuk mengetahui lingkungan tempat tinggal.

b. Menentukan kelas sampel dari populasi yang ada.

2. Tahap Pelaksanaan

a. Uji coba instrumen angket

Sebelum angket dipakai dalam penelitian, angket terlebih dahulu diujikan kepada kelas uji coba.

b. Setelah angket dinyatakan valid dan reliabel, maka angket diujikan kepada sampel yang telah ditentukan.

c. Melakukan pengajar di kelas untuk mengetahui hasil belajar Konsep Dasar PKn.

d. Melakukan analisis data sebagai hasil penelitian.

Setelah angket terkumpul kembali, maka diperiksa agar dapat dianalisis untuk mengetahui pengaruh lingkungan tempat tinggal hasil belajar mahasiswa pada mata kuliah konsep dasar PKn.

\section{HASIL DAN PEMBAHASAN}

Berdasarkan analisi data yang diperoleh dari angket dan hasil belajar mahasiswa pada mata kuliah kosep dasar PKn, maka diperoleh adalah sebagai berikut:

\section{Gambaran Lingkungan tempat tinggal}

Gambaran lingkungan tempat tinggal mahasiswa quality berastagi, khususnya kelas A11 dan A12 pada jurusan PGSD, yang dimaksud gambaran lingkungan tempat tinggal di sini adalah mahasiswa yang tinggal di lingkungan tinggal dengan orang tua dan mahasiswa yang 
Tindaon, Juwita. Pengaruh Lingkungan Tempat Tinggal Terhadap Hasil Belajar Mahasiswa Universitas Quality Berasatagi Program Studi PGSD

tinggal di lingkungan kos-kosan, berdasarkan angket dapat digambarkan pada tabel 1 sebagai berikut ini:

Tabel 1. Gambaran Lingkungan Tempat Tinggal

\begin{tabular}{llll}
\hline \multicolumn{1}{c}{ Interval } & \multicolumn{1}{c}{ Kreteria } & Frekuensi & Presentase \\
\hline $81,26 \%-100 \%$ & Sangat Baik & 2 & $4,00 \%$ \\
$62,51 \%-81,25 \%$ & Baik & 16 & $32,00 \%$ \\
$43,76 \%-62,50 \%$ & Cukup Baik & 25 & $50,00 \%$ \\
$25 \%-43,75 \%$ & Kurang Baik & 7 & $14,00 \%$ \\
\hline Jumlah & & 50 & $100,00 \%$
\end{tabular}

Sumber: Data penelitian yang diolah (2019)

Berdasarkan tabel 1 dijelaskan bahwa 50,00\% mahasiswa kelas A11 dan A12 jurusan PGSD universitas quality memiliki lingkungan tempat tinggal yang cukup baik. Sedangkan 4,00\% mahasiswa kelas A11 dan A12 jurusan PGSD universitas quality memiliki lingkungan tempat tinggal sangat baik. Lain halnya dengan 32,00\% mahasiswa kelas A11 dan A12 jurusan PGSD universitas quality memiliki lingkungan tempat tinggal yang baik. Dan 14,00\% mahasiswa kelas A11 dan A12 jurusan PGSD universitas quality memiliki lingkungan tempat tinggal yang kurang baik. Berdasarkan hal tersebut dapat ditarik kesimpulan bahwa gambaran lingkungan tempat tinggal mahasiswa kelas A11 dan A12 jurusan PGSD universitas quality berada dalam kategori cukup baik. Adapun gambaran lingkungan tempat tinggal mahasiswa kelas A11 dan A12 jurusan PGSD universitas quality dapat digambarkan pada diagram sebagai berikut:

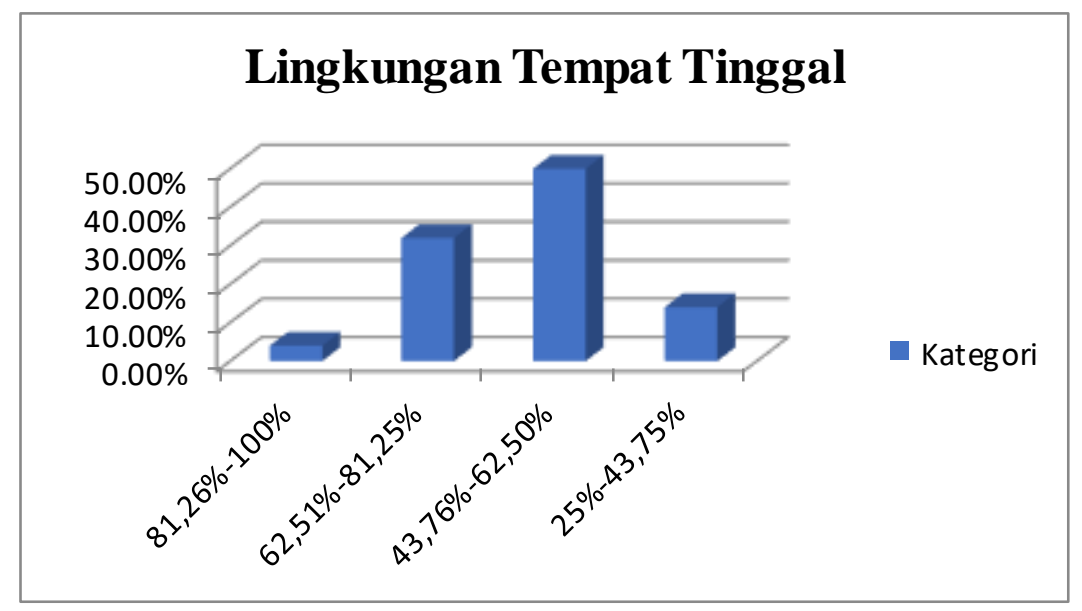

Gambar 1. Diagram Gambaran Lingkungan Tempat Tinggal

Dari 50 orang mahasiswa yang diteliti oleh peneliti 15 orang siswa yang tinggal di koskosan dan 35 orang tinggal bersama orang tua. Berdasarkan hasil analisis data angket 
mahasiswa yang tinggal di kos-kosan memiliki lingkungan tempat tinggal berkategori kurang baik, sedangkan mahasiswa yang tinggal dengan orang tua memiliki lingkungan tempat berkategori cukup baik.

\section{Gambaran Hasil Belajar Pada Mata Kuliah Konsep Dasar PKn}

Gambaran hasil belajar konsep dasar PKn mahasiswa quality berastagi, khususnya kelas A11 dan A12 pada jurusan PGSD berdasarkan tes dapat digambarkan pada tabel 2 sebagai berikut ini:

Tabel 2. Gambaran Hasil Belajar

\begin{tabular}{llll}
\hline Interval & Kreteria & Frekuensi & Presentase \\
\hline $81,00-100,00$ & Sangat Baik & 9 & $18,00 \%$ \\
$71,00-80,00$ & Baik & 18 & $36,00 \%$ \\
$61,00-70,00$ & Cukup Baik & 19 & $38,00 \%$ \\
$\leq 60,00$ & Kurang Baik & 4 & $8,00 \%$ \\
\hline Jumlah & & 50 & $100,0 \%$ \\
\hline
\end{tabular}

Sumber: Data penelitian yang diolah (2019)

Berdasarkan tabel 2. dijelaskan bahwa 38,00\% mahasiswa kelas A11 dan A12 jurusan PGSD universitas quality memiliki hasil belajar berkategori cukup baik. Sedangkan 18,00\% mahasiswa kelas A11 dan A12 jurusan PGSD universitas quality memiliki hasil belajar berkategori sangat baik. Lain halnya dengan 36,00\% mahasiswa kelas A11 dan A12 jurusan PGSD universitas quality memiliki hasil belajar berkategori baik. Dan 8,00\% mahasiswa kelas A11 dan A12 jurusan PGSD universitas quality memiliki hasil belajar berkategori kurang baik.

Berdasarkan hal tersebut dapat ditarik kesimpulan bahwa gambaran hasil belajar mahasiswa kelas A11 dan A12 pada mata kuliah konsep dasar PKn jurusan PGSD universitas quality berada dalam kategori cukup baik. Adapun gambaran hasil belajar dapat digambarkan pada diagram sebagai berikut ini: 


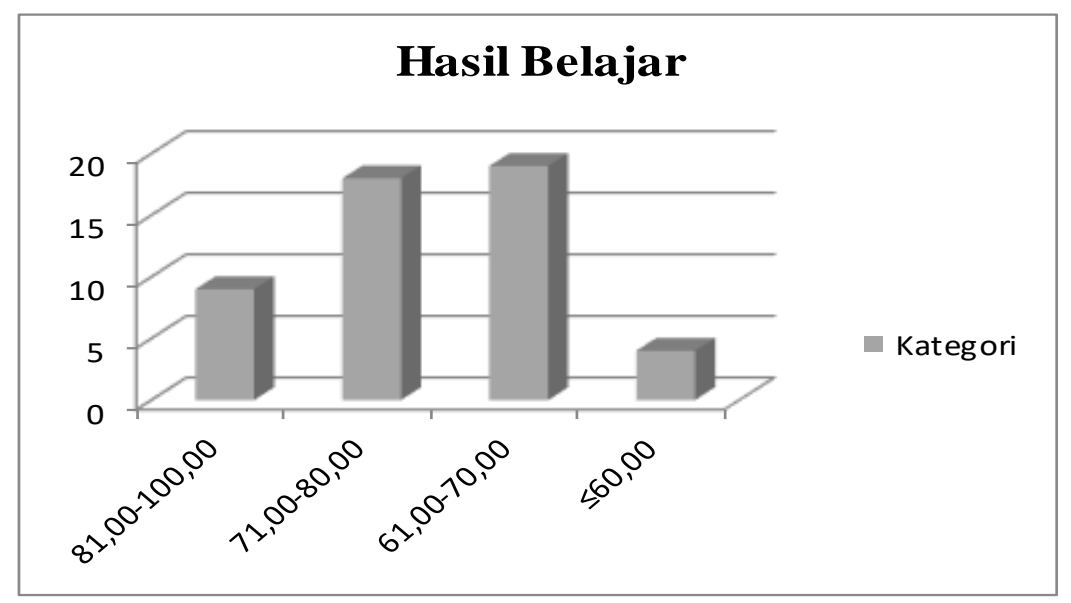

Gambar 2. Diagram Gambaran Hasil Belajar

\section{Uji Normalitas Data}

a. Uji Normalitas Angket

Hasil dari uji normalitas data untuk angket menunjukkan bahwa data tersebut berdistribusi normal. Hal ini nilai dari $\chi_{\text {hitung }}^{2}<\chi_{\text {tabel }}^{2}$. Diperoleh nilai $\chi_{\text {hitung }}^{2}=4,49$ sedangkan $\chi_{\text {tabel }}^{2}=11,1$ Dengan demikian $\chi_{\text {hitung }}^{2}<\chi_{\text {tabel }}^{2}$, sehingga Ho atau data berdistribusi normal.

b. Uji Normalitas Hasil Belajar

Hasil dari uji normalitas data untuk hasil belajar menunjukkan bahwa data tersebut berdistribusi normal. Hal ini nilai dari $\chi^{2}{ }_{\text {hitung }}<\chi^{2}{ }_{\text {tabel }}$. Diperoleh nilai $\chi^{2}{ }_{\text {hitung }}$ $=5,2$ sedangkan $\chi_{\text {tabel }}^{2}=11,1$ Dengan demikian $\chi_{\text {hitung }}^{2}<\chi_{\text {tabel }}^{2}$, sehingga Ho atau data berdistribusi normal.

\section{Uji Lineritas dan Uji Signifikan}

Untuk persamaan regeresi didapatkan persamaan $\hat{Y}=52,62+0,031 \mathrm{X}$. Uji lineritas data nilai Fhitung $=1,80$, sedangkan untuk $F_{\text {tabel }}$ atau $F_{(0,05)(18,30)}=1,96$ maka $F_{\text {tabel }}>F_{\text {hitung sehingga data }}$ dinyatakan linier. Sedangkan untuk signifikan data diperoleh $F_{\text {hitung }}=-48,96$ sedangkan $\mathrm{F}_{(0,05)(1,48)}=4,04$ maka $\mathrm{F}_{\text {tabel }}>\mathrm{F}_{\text {hitung }}$ sehingga data dinyatakan signifikan . 


\section{Uji Hipotesis Data}

a. Uji Kolerasi Product Moment

Analisi yang digunakan untuk menguji hipotesis dalam penelitian ini adalah kolerasi product moment. Di dalam penelitian ini ada dua hipotesis yaitu:

$\mathrm{H}_{0}: \rho=0$ (Tidak ada pengaruh antara lingkungan tempat tinggal terhadap hasil belajar mahasiswa pada mata kuliah konsep dasar PKn Jurusan PGSD Universitas Quality Berastagi Tahun Ajaran 2019/2020);

$\mathrm{H}_{1}: \rho \neq 0$ (Ada pengaruh antara lingkungan tempat tinggal terhadap hasil belajar mahasiswa pada mata kuliah konsep dasar PKn Jurusan PGSD Universitas Quality Berastagi Tahun Ajaran 2019/2020).

Berdasarkan nilai hitung kolerasi product moment maka nilai $\mathrm{r}=0,48$ sementara untuk nilai $r^{2}=0,06265$. Dengan harga $r$ yang bergerak ke tanda positif menyatakan ada kolerasi langsung. Yang artinya bahwa ada pengaruh langsung antara lingkungan tempat tinggal terhadap prestasi hasil belajar mahasiswa pada mata kuliah konsep dasar PKn Jurusan PGSD Universitas Quality Berastagi Tahun Ajaran 2019/2020.

Berdasarkan perhitungan kolerasi product moment diperoleh nilai $r^{2}=0,23$. Nilai menunjukkan besar pengaruh antara lingkunan tempat tinggal terhadap hasil belajar mahasiswa pada mata kuliah konsep dasar PKn Jurusan PGSD Universitas Quality Berastagi, yaitu sebesar $23 \%$.

\section{b. Uji-t}

Untuk mengetahui seberapa besar taraf signifikan berdasarkan perhitungan kolerasi product moment maka dilakukan uji-t. Maka nilai t yaitu:

$$
\begin{gathered}
t=\frac{r \sqrt{n-2}}{\sqrt{1-r^{2}}} \\
t=\frac{(0,48) \sqrt{50-2}}{\sqrt{1-0,23}} \\
t=\frac{11,71}{0,51} \\
t=22,87
\end{gathered}
$$

Sedangkan untuk nilai Presentil untuk distribusi $\mathrm{t}, \mathrm{dk}=50-2$, maka $\mathrm{dk}=48$ untuk $\alpha=$ 0,975 persamaannya $t_{(\alpha)(n-2)}$ sehingga $t_{(0,975)(48)}=2,01$ bisa dilihat pada lampiran tabel nilai 
Tindaon, Juwita. Pengaruh Lingkungan Tempat Tinggal Terhadap Hasil Belajar Mahasiswa Universitas Quality Berasatagi Program Studi PGSD

Presentil untuk distribusi t. Berdasarkan perhitungan $t_{\text {tabel }}>t_{\text {hitung }}$ maka $\mathrm{H}_{1}$ diterima atau ada pengaruh antara lingkungan tempat tinggal terhadap hasil belajar mahasiswa pada mata kuliah konsep dasar PKn Jurusan PGSD Universitas Quality Berastagi.

\section{SIMPULAN}

Dapat disimpulkan berdasarkan hasil analisis data angket mahasiswa yang tinggal di kos-kosan memiliki lingkungan tempat tinggal berkategori kurang baik, sedangkan mahasiswa yang tinggal dengan orang tua memiliki lingkungan tempat berkategori cukup baik. Sedangkan gambaran hasil belajar mahasiswa pada mata kuliah konsep dasar PKn berkategori cukup baik. Dan ada pengaruh antara lingkungan tempat tinggal terhadap hasil belajar mahasiswa pada mata kuliah konsep dasar PKn Jurusan PGSD Universitas Quality Berastagi.

\section{DAFTAR PUSTAKA}

Sudjana. (2016). Metode Statistika. Bandung: PT Tarsito.

Tirtarahardja, Umar dan S. L. La Sulo. (2015). Pengantar pendidikan. Jakarta: Rineka Cipta.

Sary, Yessy N. E. (2015). Psikologi Pendidikan (Untuk Mahasiswa Umum dan Kesehatan). Yogyakarta: Parama Publishing.

Sumadi Suryabarata. (2012). Metodologi Penelitian. Jakarta: PT Raja Grafindo Persada.

Muhibbin Syah. (2017). Psikologi Belajar. Jakarta: PT Raja Grafindo Persada. 